Journal of Economy and its Applications

ISSN: 2217-7973, URL: http:www.ilirias.com

http://www.degruyter.com/view/j/jea

Volume 5 Issue 1 (2015), Pages 1-18.

DOI: 10.1515/jea-2015-0001

DE GRUYTER

\title{
EVALUATING THE VARIATIONS IN EMPLOYMENT RELATIONS ACROSS DEVELOPING ECONOMIES: A DEGREES OF INFORMALISATION APPROACH
}

Colin C Williams, Professor of Public Policy, Sheffield University Management School, University of Sheffield, Conduit Road, Sheffield S10 1FL, United Kingdom. E-mail C.C.Williams@sheffield.ac.uk

\begin{abstract}
Conventionally, cross-national variations in employment relations systems have been compared by analysing the different characters of their formal economies (e.g., whether they are control, market or mixed economies). Recognising the persistence and even growth of informal employment, this paper examines the cross-national variations in the degree of informalisation of employment relations and then evaluates critically whether such variations are associated with: under-development (modernisation theory); high taxes, corruption and state interference (neo-liberal theory), or inadequate state intervention to protect workers from poverty (political economy theory). Reporting International Labour Organisation surveys of informal employment in 41 developing economies, the finding is that the share of the non-agricultural workforce in informal employment ranges from 83.6 per cent in India to 6.1 per cent in Serbia. Evaluating critically how these cross-national variations can be explained, support is found for the modernisation and political economy theses that associates greater informalisation with under-development and inadequate state protection of workers from poverty and the neoliberal corruption thesis. No evidence is found that greater informalisation is associated with the neo-liberal theses of higher taxes and more state interference. The theoretical and policy implications are then discussed.
\end{abstract}

Keywords: informal economy; employment relations; development economics; economic development; developing countries. 


\section{Introduction}

For much of the twentieth century, the belief was that the informal economy was an historical leftover from a pre-modern employment relations system and steadily fading from view, while work in the formal economy was ever more hegemonic (Boeke, 1942; Geertz, 1963; Lewis, 1959). There was thus little reason to pay much attention to work in the informal economy. Since the turn of the millennium, however, it has been recognised that informal employment persists and might be even growing relative to formal employment in many global regions (Adom and Williams, 2014; ILO, 2011, 2012; Jütting and Laiglesia, 2009; OECD, 2012; Schneider et al., 2010; Schneider and Williams, 2013; Williams, 2014a,b,c,d, 2015). Grounded in this recognition, the intention of this paper is to shift away from solely classifying employment relations systems across the world according to the varying character of their formal economies and instead to differentiate employment relations systems according to the degree of informalisation of employment relations.

To do this, the first section will briefly review the literature on the informalisation of employment relations, along with the contrasting theoretical explanations for participation in informal employment. Revealing that no attempt has been so far made to map or explain the variations in employment relations across developing countries using a degrees of informalisation approach, the second section then introduces an International Labour Organisation (ILO) dataset that reports the level of informal employment across 41 developing economies along with a range of World Bank development indicators that can be used to test the validity of the different explanations for the cross-national variations in the degree of informalisation of employment. The third section then reports the descriptive results of the variations in the informalisation of employment relations across these developing countries and the fourth section evaluates critically the competing explanations for the cross-national variations in the degree of informalisation of employment relations. The final section concludes by exploring the theoretical and policy implications of the findings.

Throughout this paper, and akin to the definition agreed by the $17^{\text {th }}$ International Conference of Labour Statisticians (ICLS) in 2003, informal employment refers to persons whose main jobs lack basic social or legal protections or employment benefits and these jobs may be found in formal enterprises, informal enterprises or households. This definition thus includes not only employers and own-account workers self-employed in their own informal sector enterprises, and contributing family workers and members of informal producers' cooperatives, but also employees whose employment relationship is, in law or in practice, not subject to national labour legislation, income taxation, social protection or entitlement to certain employment benefits (e.g., notice of dismissal, severance pay, paid annual or sick leave) (Hussmans, 2005; ILO, 2012; 2013; Williams and Lansky, 2013). To allow a distinction to be drawn between informal employment in informal and formal enterprises, an informal enterprise, akin to the 15th International Conference of Labour Statisticians in 1993, is here defined as a private unincorporated enterprise (i.e., not constituted as a separate legal entity independent of the individual who owns it and for which no set of accounts is kept) that is unregistered under national legislation (e.g., factories' or commercial acts, tax or social security laws, professional groups' regulatory acts) and/or employment levels are below a specific threshold (e.g. 
five employees) determined according to national circumstances (Hussmans, 2005; ILO, 2011, 2012).

\section{The informalisation of employment relations systems}

Conventionally, variations in employment relations systems across countries have analysed how the character of their formal economies differ, such as whether they are market, control or mixed economies (Arnold, 1996; Rohlf, 1998) or whether they are liberal or coordinated varieties of capitalism (Hall and Soskice, 2001). This would be appropriate and valid if informal employment was relatively minor and slowly disappearing. However, this is not the case. Indeed, since the turn of the millennium, a burgeoning literature has shown that a significant share of the workforce is in informal employment in many countries and that informal employment is growing relative to formal employment in many global regions (Buehn and Schneider, 2012; ILO, 2011; Mehrotra and Biggeri, 2007; OECD, 2012; Schneider, 2008, 2011; Williams and Shahid, 2014).

As such, a small but emerging literature has sought to map the cross-national variations in employment relations systems by analysing the degree of informalisation of employment (Buehn and Schneider, 2012; Feld and Schneider, 2010; Schneider, 2013; Williams, 2013; Williams and Youssef, 2014a,b). Until now, however, most of these studies have firstly, relied on indirect measurement methods which use proxy surrogate indicators of the level of informal employment (e.g., electricity consumption, cash in circulation), rather than data from direct surveys, when discussing cross-national variations (Buehn and Schneider 2012; Feige, 2012; Friedman et al, 2000; Lacko, 1999; Schneider and Williams, 2013), secondly, have focused on advanced economies in general, and the European Union more particularly (Schneider, 2013; Williams, 2013; Williams and Horodnic, 2015a,b; Williams and Martinez, 2014; Williams and Nadin, 2014; Williams et al., 2014) and third, and finally, have adopted simple 'logics' when explaining the crossnational variations rather than evaluating the full range of competing theoretical explanations available. To see this, the competing theories available for explaining the cross-national variations in the degree of informalisation of employment relations are here briefly reviewed.

During the twentieth century, scholarship on informal employment was dominated by a "modernisation" perspective which portrayed informal employment relations as a residue from an earlier employment relations system and their persistence a sign of "underdevelopment", "traditionalism" and "backwardness", while formal employment relations were represented as a sign of "development", "modernity", "progress" and "advancement" (Boeke, 1942; Geertz, 1963; Lewis, 1959). Seen in this manner, there was little reason to consider informal employment when discussing employment relations systems in the modern world since it was a remnant of a pre-modern employment relations system and fading from view. Cross-national variations in informal employment were thus explained to be closely associated with indicators of economic development and modernisation such as the level of GNP per capita (ILO, 2012). Over the past few decades, nevertheless, not least due to the persistence and even expansion of informal employment globally, a range of competing explanations have emerged. 
For scholars of a neo-liberal persuasion, levels of informal employment are higher in some developing countries than others due to high taxes, public sector corruption and too much state interference in the operation of the market. Informal employment is therefore a rational economic strategy pursued by those who voluntarily leave the formal economy so as to avoid the costs, time and effort associated with formal employment (e.g., Becker, 2004; De Soto, 1989, 2001; London and Hart, 2004; Nwabuzor, 2005; Sauvy, 1984; Small Business Council, 2004). As Becker (2004: 10) puts it, "informal work arrangements are a rational response by micro-entrepreneurs to over-regulation by government bureaucracies". For neo-liberal scholars, informal employment is thus a rational economic strategy pursued by those escaping high taxes and state-imposed institutional constraints (De Soto, 1989, 2001; Perry and Maloney, 2007; Small Business Council, 2004). Cross-national variations in the level of informal employment are therefore a result of high taxes, a corrupt public sector, over-regulation and state interference in the free market and the consequent remedy is tax reductions, a lowering of public sector corruption, deregulation and minimal state intervention.

For scholars of a political economy persuasion, however, the persistence and growth of informal employment is a direct by-product of a de-regulated open world economy which is integrating informal employment into capitalist production through subcontracting and outsourcing, resulting in a downward pressure on wages, income levels and welfare provision, and the growth of yet more informal employment (Castells and Portes, 1989; Davis, 2006; Gallin, 2001; Hudson, 2005; Portes, 1994; Sassen, 1996; Slavnic, 2010). For Fernandez-Kelly (2006: 18) therefore, "the informal economy is far from a vestige of earlier stages in economic development. Instead, informality is part and parcel of the processes of modernization". Informal employment is consequently viewed as necessitydriven work conducted by marginalised populations excluded from employment in the formal economy (Castells and Portes, 1989; Davis, 2006; Gallin, 2001; Hudson, 2005; Sassen, 1996).

Until now, most studies explaining cross-national variations in the degree of informalisation of employment relations have simply adopted one or other of these logics. For example, the ILO (2012) has adopted a modernisation perspective showing how informal employment decreases as GDP per capita grows and Schneider (2008) shows the validity of the tenets of the neo-liberal perspective. The only study that has evaluated critically these competing explanations for cross-national variations in the degree of informalisation of employment has focused upon the member states of the European Union and found evidence to support the tenets of both the modernisation and political economy perspectives but little evidence to support most of the tenets of the neo-liberal perspective (Williams, 2013). No studies have yet evaluated the validity of these competing explanations in the context of the developing world. This paper therefore seeks to fill that gap.

\section{Methodology: examining cross-national variations in employment relations systems}

To estimate the cross-national variations in the degree of informalisation of employment relations systems, the ILO surveys conducted on the level of informal employment in 41 developing countries are here analysed. This is the only cross-nationally comparable data 
currently available on the degree of informalisation of employment relations in developing countries that uses a common broad definition of informal employment across all countries and the same survey methodology to collect data in the form of an ILO Department of Statistics questionnaire sent to countries (for further details, see ILO 2012). This survey methodology excludes employment in agriculture, hunting, forestry and fishing. When examining the share of the non-agricultural workforce involved in informal employment, moreover, it is the self-reported main job of people having more than one job that is counted, not least so as to avoid any small-scale odd-jobs in the informal economy being counted.

To move beyond a simple descriptive account of the cross-national variations in the degree of informalisation of employment and towards evaluating critically the competing explanations for these variations, indicators are employed from the World Bank database of development indicators for the year in which the ILO survey was undertaken in each country (World Bank, 2013). The only indicator evaluated using a non-official data source is taken from Transparency International's widely used corruption perceptions index (CPI) for the relevant year in each country (Transparency International, 2013).

To evaluate the validity of the modernisation theory, and similar to previous studies (ILO, 2012; Yamada, 1996), the indicator here used is GNP per capita (ILO, 2012). To evaluate the neo-liberal theory that higher levels of informal employment are the product of high taxes, meanwhile, and similar to previous studies (Eurofound, 2013; European Commission, 2013), the following three World Bank (2013) country-level indicators are analysed:

Taxes on goods and services as a percentage of revenue. This includes general sales and turnover or value added taxes, selective excises on goods, selective taxes on services, taxes on the use of goods or property, taxes on extraction and production of minerals, and profits of fiscal monopolies;

Taxes on revenue (excluding grants) as a percentage of GDP. Here, revenue covers cash receipts from taxes, social contributions, and other revenues such as fines, fees, rent, and income from property or sales.

Tax revenue as a percentage of GDP. Tax revenue here refers to compulsory transfers to the central government for public purposes. Certain compulsory transfers such as fines, penalties, and most social security contributions are excluded. Refunds and corrections of erroneously collected tax revenue are treated as negative revenue.

Meanwhile, the corruption thesis of the neo-liberal perspective is assessed using:

Transparency International's Corruption Perceptions Index (CPI) (Transparency International 2013). This composite index of perceptions of public sector corruption draws on 14 expert opinion surveys and countries are scored on a $0-10$ scale with zero indicating high levels and 10 low levels of perceived public sector corruption.

To evaluate the neo-liberal thesis that state interference produces higher degrees of informalisation as well as the political economy thesis that it results from inadequate levels of state intervention, and again similar to previous studies (Eurofound, 2013; European Commission, 2013), the following indicator is evaluated:

Social contributions as a \% of revenue. Social contributions include social security contributions by employees, employers, and self-employed individuals, and other contributions whose source cannot be determined. Such contributions also include actual or imputed contributions to social insurance schemes operated by governments. 
Finally, and to analyse the political economy tenet that the degree of informalisation of employment is associated with the level of poverty, the variable analysed is the percentage of the population living below the national poverty line (ILO, 2012).

Given the small sample size of just 41 cases, a multivariate regression analysis cannot be conducted here. Instead, the relationships between the degree of informalisation and wider economic and social conditions are evaluated using bivariate regression analyses. Spearman's rank correlation coefficient $\left(r_{s}\right)$ is employed to do this due to the nonparametric nature of the data. Despite this limitation of using only bivariate regression analysis, however, and as will be revealed, meaningful findings are produced with regard to the validity of the different theoretical perspectives.

Firstly, therefore, some descriptive statistics on the cross-national variations in the degree of informalisation of employment in developing countries will be reported and secondly, a preliminary analysis of relationship between the degree of informalisation and the wider economic and social conditions which each theory purports are correlated with higher degrees of informalisation so as to evaluate the competing theories in relation to the developing world.

\section{Findings: cross-national variations in the informalisation of employment relations}

Examining the findings for the 41 developing countries for which ILO comparable data is available on the degree of informalisation of employment, and taking into account the variable size of the workforce in each country, the finding is that over one-third (34.4 per cent) of non-agricultural workers are in informal employment as their main job across these 41 developing economies. Informal employment, therefore, is not some minor leftover of little importance but a sizeable realm employing a large share of the workforce in these developing countries.

As Table 1 displays, however, there are marked cross-national variations in the proportion of the non-agricultural workforce in informal employment ranging from 83.6 per cent in India to 6.1 per cent in Serbia. Indeed, in 24 (59 per cent) of the 41 nations, over half of the non-agricultural workforce is in informal employment. Indeed, using the graphic representation in Figure 1 that positions employment relations systems in developing countries on a spectrum from wholly formal to wholly informal with many variations in-between, the final column of Table 1 shows how countries are distributed along this continuum.

\section{INSERT TABLE 1 ABOUT HERE}

\section{INSERT FIGURE 1 ABOUT HERE}

This reveals that although no developing countries have all the workforce in either formal or informal employment and none are 'nearly informal' economies (with 90-99 per cent of the workforce in informal jobs), 5 per cent are 'dominantly informal' economies (with 80-89 per cent in informal jobs), 20 per cent are 'largely informal' economies (with 70-79 per cent in informal jobs), 22 per cent are 'mostly informal' economies (60-69 per cent in informal jobs), 12 per cent are 'semi-informal' economies (50-59 per cent in informal 
jobs), 20 per cent are 'semi-formal' economies (40-49 per cent in informal jobs), 12 per cent are 'mostly formal' economies (30-39 per cent in informal jobs), none are 'largely formal' economies (20-29 per cent in informal jobs), 7 per cent are 'dominantly formal' economies (10-19 per cent in informal jobs) and 2 per cent 'nearly formal' economies (19 per cent in informal jobs). These developing countries, in consequence, are heavily clustered in the middle of the continuum, mostly towards the informal end of the continuum.

There are also some significant variations in the degree of informalisation of employment relations across global regions. To analyse this, and as column 3 of Table 1 displays, the 41 countries are allocated using the World Bank (2013) classification to six global regions. Analysing how the degree of informalisation of employment varies across these global regions, the finding is that the weighted proportion of the non-agricultural workforce in informal employment is 26.8 per cent in Europe and Central Asia, 44.0 per cent in East Asia and the Pacific, 50.5 per cent in Latin America and the Caribbean, 51.5 per cent in the Middle East and North Africa, 53.2 per cent in sub-Saharan Africa and 82.6 per cent in South Asia. The degree of informalisation of employment relations, therefore, is far from even across global regions.

There is also a strong correlation between the degree of informalisation of employment in a country, measured in terms of the proportion of the non-agricultural workforce in informal employment, and the intensity of informalisation, measured by the share of all informal employment which is in informal rather than formal enterprises. To see this, columns 4 and 5 of Table 1 report the degree and intensity of the informalisation of employment respectively. Examining the intensity of the informalisation of employment, the finding is that across all 41 developing countries, some two-thirds (68 per cent) of all informal employment is in informal sector enterprises. Again, however, there are marked cross-national variations, ranging from 86.2 per cent in Mali to 27.2 per cent in Nicaragua. To analyse the correlation between the degree and intensity of the informalisation of employment, Figure 2 graphically displays that there is a statistically significant association. The greater is the degree of informalisation of employment in a country, the higher is the intensity of the informalisation of employment (i.e., the more likely is informal employment to be located in informal enterprises). Indeed, using Spearman's rank correlation coefficient $\left(\mathrm{r}_{\mathrm{s}}\right)$ due to the non-parametric nature of the data, the finding is that this is a statistically significant within a 95 per cent confidence interval $\left(\mathrm{r}_{\mathrm{s}}=-.584^{* *}\right)$.

\section{INSERT FIGURE 2 ABOUT HERE}

Given these findings regarding the cross-national variations in the degree of informalisation of employment, attention now turns towards evaluating critically the various competing theories that have sought to explain these variations.

\section{Analysis: evaluating the competing theories}

To conduct a preliminary analysis of the validity of each of the three theories that have sought to explain these cross-national variations in the degree of informalisation of 
employment, the association between the degree of informalisation and the various characteristics that deem to be important determinants are here investigated.

Starting with the modernisation perspective that the share of informal employment is lower in wealthier economies and greater in less developed economies, the correlation between the degree of informalisation and GNP per capita can be analysed across these 41 developing countries. Using Spearman's rank correlation coefficient, the finding is that there is a strong statistically significant relationship between the degree of informalisation of employment in a country and its GNP per capita $\left(\mathrm{r}_{\mathrm{s}}=-.560 * *\right)$. The direction of this relationship is that the degree of informalisation is higher in developing economies with lower levels of GNP per capita. However, and similar to previous studies that reach the same conclusion (ILO, 2012; Yamada, 1996), it is not possible to here establish the direction of the correlation in terms of any cause-effect relationship. This, in consequence, is a limitation of both this and previous studies.

To evaluate the neo-liberal explanation that informalisation is a result of higher taxes, corruption and state interference in the operation of the free market, the first step is to analyse the neo-liberal assertion that informalisation is greater when public sector corruption is higher because this results in citizens exiting the formal economy so as to seek livelihoods beyond the corrupt public sector officials, the finding is that a close statistically significant association is identified $\left(\mathrm{r}_{\mathrm{s}}=-.564 * *\right)$. Countries with higher perceived levels of public sector corruption have a greater degree of informalisation of employment.

Turning to the neo-liberal assertion that higher levels of informal employment are a product of exit from the formal economy due to high taxes, cross-national variations in the degree of informalisation of employment are here compared with cross-national variations in tax rates. Beginning with the relationship between the cross-national variations in the scale of informal employment and the level of taxes on goods and services as a percentage of revenue, the finding is that there is a statistically significant correlation $\left(\mathrm{r}_{\mathrm{s}}=-.400^{* *}\right)$. However, its direction is the inverse of the neo-liberal suggestion. The degree of informalisation of employment decreases as taxes on goods and services increases. Given that this contests a central tenet of neo-liberal discourse, the relationship between informalisation and two further measures of tax levels are here analysed. Analysing cross-national variations in the level of revenue (excluding grants) as a share of GDP and the degree of informalisation, a statistically significant association is identified $\left(\mathrm{r}_{\mathrm{s}}=-.626^{* *}\right)$. Again, however, it is in the opposite direction to that suggested by neo-liberal theory. It is similarly the case when the association between cross-national variations in the level of tax revenue as a proportion of GDP and cross-national variations in the informalisation of employment is analysed. There is once more a strong statistically significant association $\left(\mathrm{r}_{\mathrm{s}}=-.637^{* *}\right)$ but again, the association is the inverse of what neo-liberal theory asserts. Across all three measures of tax rates, therefore, the direction of the statistically significant relationship is that the degree of informalisation of employment is lower in nations with higher tax rates. One reason that higher tax levels are correlated with lower levels of informal employment may be that this provides greater state revenue to enable social transfers so that citizens can receive some level of social protection.

To evaluate both this and the validity of the neo-liberal argument that state interference in the operation of the market leads to higher degrees of informalisation of employment, as 
well as the contrary political economy assertion that the degree of informalisation of employment reduces with greater state intervention, the relationship between crossnational variations in the degree of informalisation of employment and the level of social contributions as a percentage of revenue can be analysed. The finding is that a significant correlation is identified $\left(\mathrm{r}_{\mathrm{s}}=-.560 *\right)$. The direction of the relationship is that the degree of informalisation reduces as social contributions rise as a share of revenue, intimating support for the political economy explanation. No evidence is therefore found to support the neo-liberal argument that state interference leads to the informalisation of employment. Instead, the political economy thesis is supported that the informalisation of employment is associated with too little state intervention in the form of social protection. Is it also the case, therefore, that evidence can be found to support the political economy thesis that cross-national variations in the degree of informalisation are associated with the level of poverty? Again, a strong statistically significant relationship is found between cross-national variations in the proportion of the population living below the national poverty line and the degree of informalisation of employment $\left(\mathrm{r}_{\mathrm{s}}=.396^{*}\right)$. The direction of this relationship is that the greater is the share of the population living below the national poverty line, the greater is the informalisation of employment relations systems, intimating that informalisation might well be a last resort turned to by marginalised groups with no other means of livelihood or support, as posited by the political economy perspective.

\section{Conclusions}

To chart the variations in employment relations systems across developing economies, this paper has moved beyond analysing the character of their formal economies (e.g., whether they are control, market or mixed economies) and instead differentiated employment relations systems by examining the cross-national variations in the degree of informalisation of employment. Reporting ILO surveys of the level of informal employment conducted in 41 developing economies, the finding is that 34.4 per cent of the non-agricultural workforce participates in informal employment as their main job, although there are marked cross-national variations, ranging from 83.6 per cent in India to 6.1 per cent in Serbia. Informal employment, in consequence, is not some small segment of the labour market of limited importance. Indeed, in 59 per cent of the countries surveyed, the majority of the non-agricultural workforce is engaged in informal employment.

To explain the cross-national variations in the degree of informalisation of employment, an exploratory analysis has been conducted of the validity of three competing theoretical perspectives. These variously contend that higher degrees of informalisation are a product of economic under-development (modernisation theory), corruption, higher taxes and state interference (neo-liberal theory) and inadequate state intervention to protect workers from poverty (political economy theory). Evidence has been found to support the modernisation and political economy theses that associate's greater informalisation with under-development and inadequate state protection of workers from poverty respectively and the neo-liberal corruption thesis that the degree of informalisation is higher in countries where the perception of public sector corruption is greater. However, no 
evidence has been found to support the validity of the neo-liberal theses that greater informalisation is associated with higher taxes and more state interference.

The theoretical implication of this study of cross-national variations of the degree of informalisation, therefore, is that a combination of previous explanations is required when studying developing economies. Akin to the previous finding when studying this issue in relation to the advanced economies of the European Union (Williams, 2013), albeit using a data set that is not comparable with this data set, the finding is that greater degrees of informalisation are associated with lower GNP per capita, higher levels of public sector corruption and lower levels of state intervention in the form of lower tax rates and social transfers to protect workers from poverty. The very tentative conclusion, therefore, is that similar characteristics are associated with greater degrees of informalisation of employment in both developed and developing countries. This now needs to be further evaluated not only in relation to a wider range of developed and developing economies as well as using time-series data for individual nations but also, if possible, multivariate regression analysis is required on a larger sample size to determine how important each characteristic is to the final outcome whilst controlling for the other characteristics. The hindrance to achieving this, however, is the lack of cross-national comparative data on the informalisation of employment relations currently available to undertake such analyses.

These findings also have policy implications for governments. Currently, the policy debate surrounding informalisation is over the balance between whether targeted repressive measures and/or targeted incentives to facilitate formalisation (Dibben and Williams, 2012; Eurofound, 2013; Feld and Larsen, 2012; OECD, 2012; Williams and Nadin, 2012; Williams et al., 2013). This paper, however, displays that it is important to focus upon wider economic and social policies associated with the overarching modernisation of economies, tackling corruption, tax rates, social protection and poverty alleviation. In other words, this paper tentatively reveals that tackling the informalisation of employment relations requires appropriate wider economic and social policies. Put another way, pursuing targeted measures per se may be necessary but seems insufficient for tackling the informalisation of employment relations.

In sum, this paper has adopted an alternative analytical framework for classifying crossnational variations in employment relations systems by transcending the conventional focus upon the differential character of formal economic systems across countries. Recognising the marked cross-national variations in the degree of informalisation of employment, greater attention has been paid to differentiating economies by the degree of informalisation of their employment relations systems. This approach to classifying employment relations systems, of course, does not have to be viewed as an alternative to the conventional approach. Indeed, future research might well seek to combine these two approaches to classifying employment relations systems when analysing cross-national variations in employment relations. If this paper thus encourages further research using a degrees of informalisation approach towards employment relations systems, it will have achieved its intention. If it also leads to scholars of employment relations systems to synthesis the conventional approach examining the character of formal economies with this new approach documenting the degrees of informalisation of employment, then it will have achieved its wider objective. 


\section{References}

Adom, K. and Williams, C.C. (2014) "Evaluating the explanations for the informal economy in third world cities: some evidence from Koforidua in the eastern region of Ghana", International Entrepreneurship and Management Journal, Vol. 10, No. 2, pp. 427-445.

Arnold, R.A. (1996), Economics, West Publishing, St Paul, MN.

Becker, K.F. (2004), The informal economy, Swedish International Development Agency, Stockholm.

Boeke, J.H. (1942), Economies and economic policy in dual societies, Tjeenk Willnik, Harlem.

Bureau, S. and Fendt, J. (2011), "Entrepreneurship in the informal economy: why it matters", International Journal of Entrepreneurship and Innovation, Vol. 12 No. 2, pp. 85-94.

Castells, M. and Portes, A. (1989), "World underneath: the origins, dynamics and effects of the informal economy", in Portes, A., Castells, M. and Benton, L.A. (Eds.), The informal economy: studies in advanced and less developing countries, John Hopkins University Press, Baltimore, pp. 19-41.

Davis, M. (2006), Planet of Slums, Verso, London.

De Soto, H. (1989), The Other Path, Harper and Row, London.

De Soto, H. (2001), The Mystery of Capital: why capitalism triumphs in the West and fails everywhere else, Black Swan, London. 
Dibben, P. and Williams, C.C. (2012), "Varieties of capitalism and employment relations: informally dominated market economies", Industrial Relations: a Review of Economy and Society, Vol. 51 No. S1, pp. 563-82.

Eurofound (2013), Tackling Undeclared Work in 27 European Union Member States and Norway: approaches and measures since 2008, Eurofound, Dublin.

European Commission (2013), Employment and Social Developments in Europe 2013, European Commission, Brussels.

Feige, E.L. (2012), The myth of the "cashless society"? How much of America's currency is overseas, http://www.bundesbank.de/Redaktion/EN/Downloads/Core_business_areas/Cash _management/conferences/2012/2012_02_27_eltville_03_feige_paper.pdf?_blob =publicationFile (last accessed 12 January 2014).

Feld, L.P. and Larsen, C. (2012), Undeclared work, deterrence and social norms: the case of Germany, Springer Verlag, Berlin.

Feld, L. and Schneider, F. (2010), "Survey on the shadow economy and undeclared earnings in OECD Countries", German Economic Review, Vol. 11, pp. 109-49.

Fernandez-Kelly, P. (2006), "Introduction”, in Fernandez-Kelly, P. and Shefner, J. (Eds.), Out of the Shadows: political action and the informal economy in Latin America, Pennsylvania State University Press, Pennsylvania, pp. 1-18.

Friedman, E., Johnson, S., Kaufmann, D. and Zoido, P. (2000), "Dodging the grabbing hand: the determinants of unofficial activity in 69 countries", Journal of Public Economics, Vol. 76 No. 3, pp. 459-93. 
Gallin, D. (2001), "Propositions on trade unions and informal employment in time of globalisation", Antipode, Vol. 19 No. 4, pp. 531-49.

Geertz, C. (1963), Old Societies and New States: the quest for modernity in Asia and Africa, Free Press, Glencoe, IL.

Hall, P. and Soskice, D. (2001) (eds.), Varieties of Capitalism: The Institutional Foundations of Comparative Advantage, Oxford University Press, Oxford.

Hudson, R. (2005), Economic Geographies: circuits, flows and spaces, Sage, London.

Hussmanns, R. (2005), Measuring the informal economy: from employment in the informal sector to informal employment, Working Paper no. 53, ILO Bureau of Statistics, Geneva.

ILO (2002), Decent work and the informal economy, International Labour Office, Geneva.

ILO (2011), Statistical update on employment in the informal economy, ILO Department of Statistics, Geneva.

ILO (2012), Statistical update on employment in the informal economy, ILO Department of Statistics, Geneva.

Jütting, J.P. and Laiglesia, J.R. (2009), "Employment, poverty reduction and development: what's new?", in Jütting, J.P. and Laiglesia, J.R. (Eds.), Is Informal Normal? Towards more and better jobs in developing countries, OECD, Paris, pp. $1-20$.

Lacko, M. (1999), "Electricity intensity and the unrecorded economy in post-socialist countries", in Feige, E.L. and Ott, K. (Eds.), Underground Economies in 
Transition: unrecorded activity, tax evasion, corruption and organized crime, Ashgate, Aldershot, pp. 42-65.

Lewis, A. (1959), The Theory of Economic Growth, Allen and Unwin, London.

London, T. and Hart, S.L. (2004), "Reinventing strategies for emerging markets: beyond the transnational model”, Journal of International Business Studies, Vol. 35 No. 5, pp.350-70.

Mehrotra, S. and Biggeri, M. (2007), (eds.), Asian informal workers: global risks, local protection, Routledge, London.

Nwabuzor, A. (2005), "Corruption and development: new initiatives in economic openness and strengthened rule of law", Journal of Business Ethics, Vol. 59 No. 1/2, pp. 121-38.

OECD (2012), Reducing opportunities for tax non-compliance in the underground economy, OECD, Paris.

Perry, G.E. and Maloney, W.F. (2007), “Overview: Informality - exit and exclusion”, in Perry, G.E., Maloney, W.F., Arias, O.S., Fajnzylber, P., Mason, A.D. and Saavedra-Chanduvi, J. (Eds), Informality: exit and exclusion, World Bank, Washington DC, pp. 1-20.

Portes, A. (1994), "The informal economy and its paradoxes", in Smelser, N.J. and Swedberg, R. (Eds.), The handbook of economic sociology, Princeton University Press, Princeton, pp. 142-65.

Rohlf, W.D. (1998), Introduction to Economic Reasoning, Addison-Wesley, London. Sassen, S. (1996), "Service employment regimes and the new inequality", in Mingione, E. (ed.), Urban poverty and the underclass, Basil Blackwell, Oxford, pp. 142-59. 
Sauvy, A. (1984), Le Travail Noir et l'Economie de Demain, Calmann-Levy, Paris.

Schneider, F (2008) (ed.), The Hidden Economy, Edward Elgar, Cheltenham.

Schneider F (2011) (ed.), Handbook on the Shadow Economy, Edward Elgar, Cheltenham.

Schneider, F. (2013), Size and development of the shadow economy of 31 European and 5 other OECD countries from 2003 to 2013: a further decline. http://www.econ.jku.at/members/Schneider/files/publications/2013/ShadEcEurop e31 Jan2013.pdf (last accessed 10 January 2014)

Schneider, F. and Williams, C.C. (2013), The Shadow Economy, Institute of Economic Affairs, London.

Schneider, F., Buehn, A. and Montenegro, A. (2010), "New estimates for the shadow economies all over the world”, International Economic Journal, Vol. 24, pp. 44361.

Slavnic, Z. (2010), "Political economy of informalization”, European Societies, Vol. 12 No. 1, pp. 3-23.

Small Business Council (2004), Small Business in the Informal Economy: making the transition to the formal economy, Small Business Council, London.

Transparency International (2013), Corruption Perceptions Index (CPI) (available at: http://www.transparency.org/research/cpi/cpi_2007 (last accessed 10 January 2014)

Williams, C.C. (2010), "Evaluating the nature of undeclared work in South-Eastern Europe", Employee Relations, Vol. 32 No. 3, pp. 212 - 226. 
Williams, C.C. (2013), "Evaluating cross-national variations in the extent and nature of informal employment in the European Union”, Industrial Relations Journal, Vol. 44 No. 5-6, pp. 479-94.

Williams, C.C. (2014a) "Explaining cross-national variations in the size of the shadow economy in Central and Eastern Europe", Debatte: Journal of Contemporary Central and Eastern Europe, Vol. 22, No. 2, pp. 241-258

Williams, C.C. (2014b) "Explaining cross-national variations in the prevalence and character of undeclared employment in the European Union", European Spatial Research and Policy, Vol. 21, No.2, pp. 115-132.

Williams, C.C. (2014c) "Explaining cross-national variations in the prevalence of envelope wages: some lessons from a 2013 Eurobarometer survey", Industrial Relations Journal, Vol. 45, No. 6, pp. 524-542.

Williams, C.C. (2014d) "Out of the shadows: a classification of economies by the size and character of their informal sector", Work, Employment and Society, Vol. 28, No. 5 , pp. $735-53$

Williams, C.C. (2015) "Tackling employment in the informal economy: a critical evaluation of the neo-liberal policy approach", Economic and Industrial Democracy: an International Journal, http://dx.doi.org/10.1177/0143831X14557961

Williams, C.C. and Horodnic, I. (2015a) "Rethinking the marginalisation thesis: an evaluation of the socio-spatial variations in undeclared work in the European Union", Employee Relations, Vol. 37. No.1, pp. 48 - 65. 
Williams, C.C. and Horodnic, I. (2015b) "Explaining the prevalence of illegitimate wage practices in Southern Europe: an institutional analysis", South European Society and Politics, http://dx.doi.org/10.1080/13608746.2015.1013518

Williams, C.C. and Lansky, M. (2013), "Informal employment in developed and developing economies: perspectives and policy responses", International Labour Review, Vol. 152 No. 3-4, pp. 355-80.

Williams, C.C. and Martinez-Perez, A. (2014) "Why do consumers purchase goods and services in the informal economy?", Journal of Business Research, Vol. 67, No. 5, pp. 802-806.

Williams, C.C. and Nadin, S. (2012), “Tackling the hidden enterprise culture: government policies to support the formalization of informal entrepreneurship", Entrepreneurship and Regional Development, Vol. 24 No. 9-10, pp. 895-915.

Williams, C.C. and Nadin, S. (2014) "Evaluating the participation of the unemployed in undeclared work: evidence from a 27 nation European survey", European Societies, Vol. 16, No. 1, pp. 68-89.

Williams, C.C. and Shahid, M. (2015) "Informal entrepreneurship and institutional theory: explaining the varying degrees of (in)formalisation of entrepreneurs in Pakistan”, Entrepreneurship and Regional Development, http://dx.doi.org/10.1080/08985626.2014.963889

Williams, C.C. and Youssef, Y (2014a) "Classifying Latin American economies: a degrees of informalisation approach", International Journal of Business Administration, Vol. 5, No. 3, pp. $73-85$ 
Williams, C.C. and Youssef, Y (2014b) "Combating informal employment in Latin America: a critical evaluation of the neo-liberal approach", Research in World Economy, Vol. 5, No. 2, pp. http://dx.doi.org/10.5430/rwe.v5n2p1

Williams, C.C., Round, J. and Rodgers, P. (2013), The Role of Informal Economies in the Post-Soviet World: the end of transition?, Routledge, London.

Williams, C.C., Franic, J. and Dzhekova, R. (2014) "Explaining and tackling the undeclared economy in Bulgaria: an institutional asymmetry perspective", SouthEastern Europe Journal of Economics and Business, Vol. 9, No. 2, pp. 33-45.

World Bank (2013), World Development Indicators, World Bank, Washington DC. http://data.worldbank.org/data-catalog/world-development-indicators $\quad$ (Last accessed 10 January 2014)

Yamada, G. (1996), "Urban informal employment and self-employment in developing countries: theory and evidence", Economic Development and Cultural Change, Vol. 44 No. 2, pp. 244-66. 
Table 1 Degree of informalisation of employment relations in 41 developing countries

\begin{tabular}{|c|c|c|c|c|c|c|}
\hline Country & Year & $\begin{array}{l}\text { Global region (Wo } \\
\text { Bank classification) }\end{array}$ & & $\begin{array}{c}\% \text { of jobs } \\
\text { in } \\
\text { informal } \\
\text { employme } \\
\text { nt }\end{array}$ & $\begin{array}{l}\text { \% of } \\
\text { informal } \\
\text { employme } \\
\text { nt in } \\
\text { informal } \\
\text { sector } \\
\text { enterprises }\end{array}$ & $\begin{array}{l}\text { Type of } \\
\text { economy }\end{array}$ \\
\hline India & 2009 & South Asia & & 83.6 & 80.0 & $\begin{array}{l}\text { Dominantly } \\
\text { formal }\end{array}$ \\
\hline Mali & 2004 & Sub-Saharan Africa & & 81.8 & 86.2 & $\begin{array}{l}\text { Dominantly } \\
\text { formal }\end{array}$ \\
\hline Pakistan & 2009 & South Asia & & 78.4 & 89.4 & Largely formal \\
\hline Tanzania & 2005 & Sub-Saharan Africa & & 76.2 & 67.2 & Largely formal \\
\hline Bolivia & 2006 & $\begin{array}{l}\text { Latin America } \\
\text { Caribbean }\end{array}$ & $\&$ & 75.1 & 68.8 & Largely formal \\
\hline Honduras & 2009 & $\begin{array}{l}\text { Latin America } \\
\text { Caribbean }\end{array}$ & $\&$ & 73.9 & 77.0 & Largely formal \\
\hline $\begin{array}{l}\text { Madagasc } \\
\text { ar }\end{array}$ & 2005 & Sub-Saharan Africa & & 73.6 & 71.0 & Largely formal \\
\hline Indonesia & 2009 & East Asia \& Pacific & & 72.5 & 83.2 & Largely formal \\
\hline Paraguay & 2009 & $\begin{array}{l}\text { Latin America } \\
\text { Caribbean }\end{array}$ & $\&$ & 70.7 & 53.6 & Largely formal \\
\hline $\begin{array}{l}\text { Philippine } \\
\text { s }\end{array}$ & 2008 & East Asia and Pacific & & 70.1 & 83.6 & Largely formal \\
\hline Peru & 2009 & $\begin{array}{l}\text { Latin America } \\
\text { Caribbean }\end{array}$ & $\&$ & 69.9 & 69.0 & Mostly informal \\
\hline Zambia & 2008 & Sub-Saharan Africa & & 69.5 & 83.2 & Mostly informal \\
\hline Uganda & 2010 & Sub-Saharan Africa & & 69.4 & 80.3 & Mostly informal \\
\hline Vietnam & 2009 & East Asia \& Pacific & & 68.2 & 63.4 & Mostly informal \\
\hline $\begin{array}{l}\text { El } \\
\text { Salvador }\end{array}$ & 2009 & $\begin{array}{l}\text { Latin America } \\
\text { Caribbean }\end{array}$ & $\&$ & 66.4 & 77.7 & Mostly informal \\
\hline Nicaragua & 2009 & $\begin{array}{l}\text { Latin America } \\
\text { Caribbean }\end{array}$ & $\&$ & 65.7 & 27.2 & Mostly informal \\
\hline Sri Lanka & 2009 & South Asia & & 62.1 & 71.3 & Mostly informal \\
\hline Ecuador & 2009 & $\begin{array}{l}\text { Latin America } \\
\text { Caribbean }\end{array}$ & $\&$ & 60.9 & 60.6 & Mostly informal \\
\hline Liberia & 2010 & Sub-Saharan Africa & & 60.0 & 72.0 & Mostly informal \\
\hline Colombia & 2010 & $\begin{array}{l}\text { Latin America } \\
\text { Caribbean }\end{array}$ & $\&$ & 59.6 & 84.4 & Semi informal \\
\hline $\begin{array}{l}\text { West } \\
\text { Bank } \quad \& \\
\text { Gaza }\end{array}$ & 2010 & $\begin{array}{l}\text { Middle East \& No } \\
\text { Africa }\end{array}$ & & 58.5 & 38.9 & Semi informal \\
\hline Mexico & 2009 & $\begin{array}{l}\text { Latin America } \\
\text { Caribbean }\end{array}$ & $\&$ & 53.7 & 62.4 & Semi informal \\
\hline Zimbabw & 2004 & Sub-Saharan Africa & & 51.6 & - & Semi informal \\
\hline
\end{tabular}




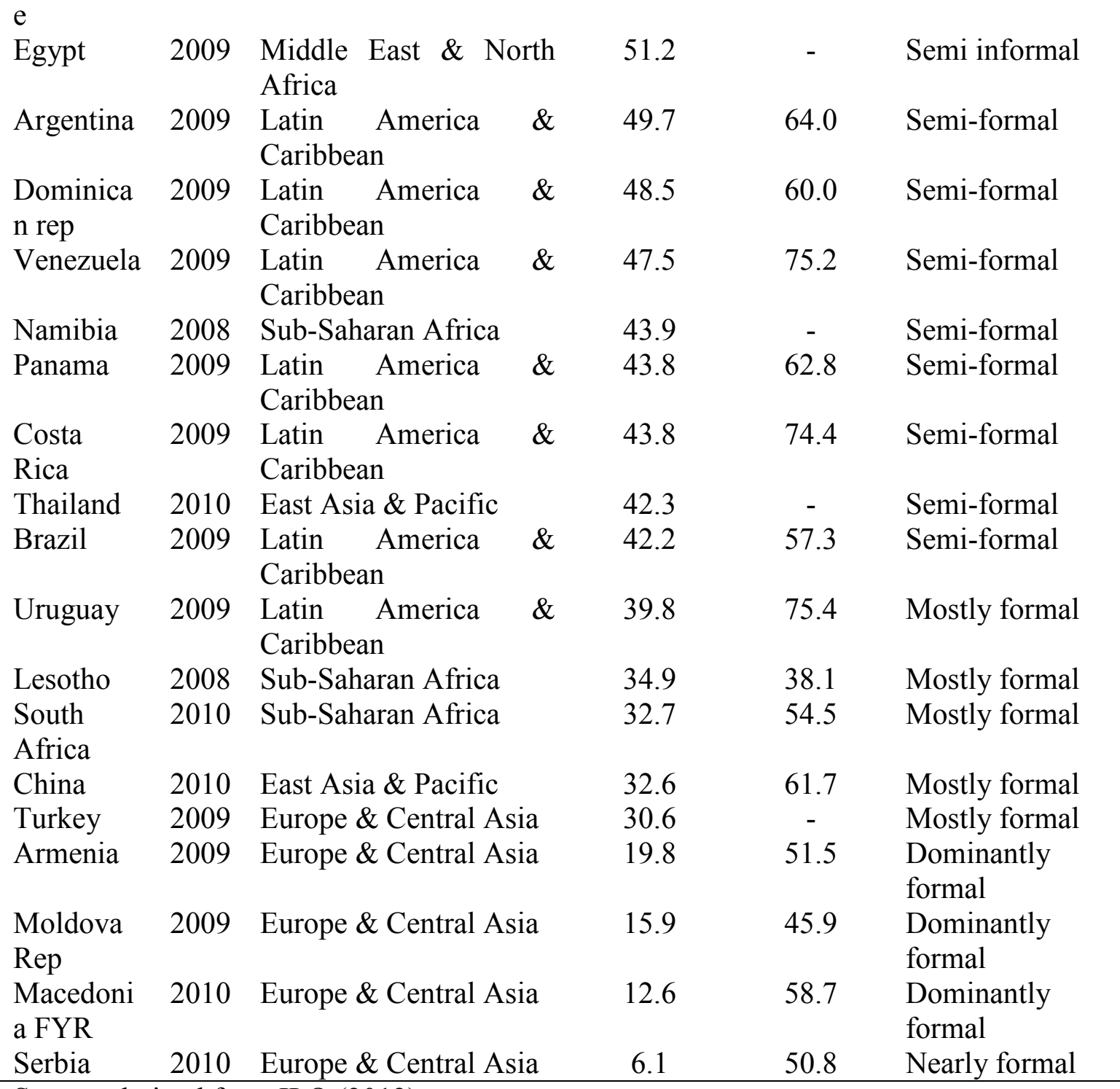

Source: derived from ILO (2012)

Figure 1. Typology of employment relations systems: by degree of formalisation of employment relations

Nearly Domin Largely Mostly Semi- Semi- Mostly Largely Domin Nearly formal antly formal formal formal informal formal informal antly informal formal informal

$\begin{array}{llllllllll}\longleftrightarrow & 10 & 20 & 30 & 40 & 50 & 60 & 70 & 80 & 90\end{array}$




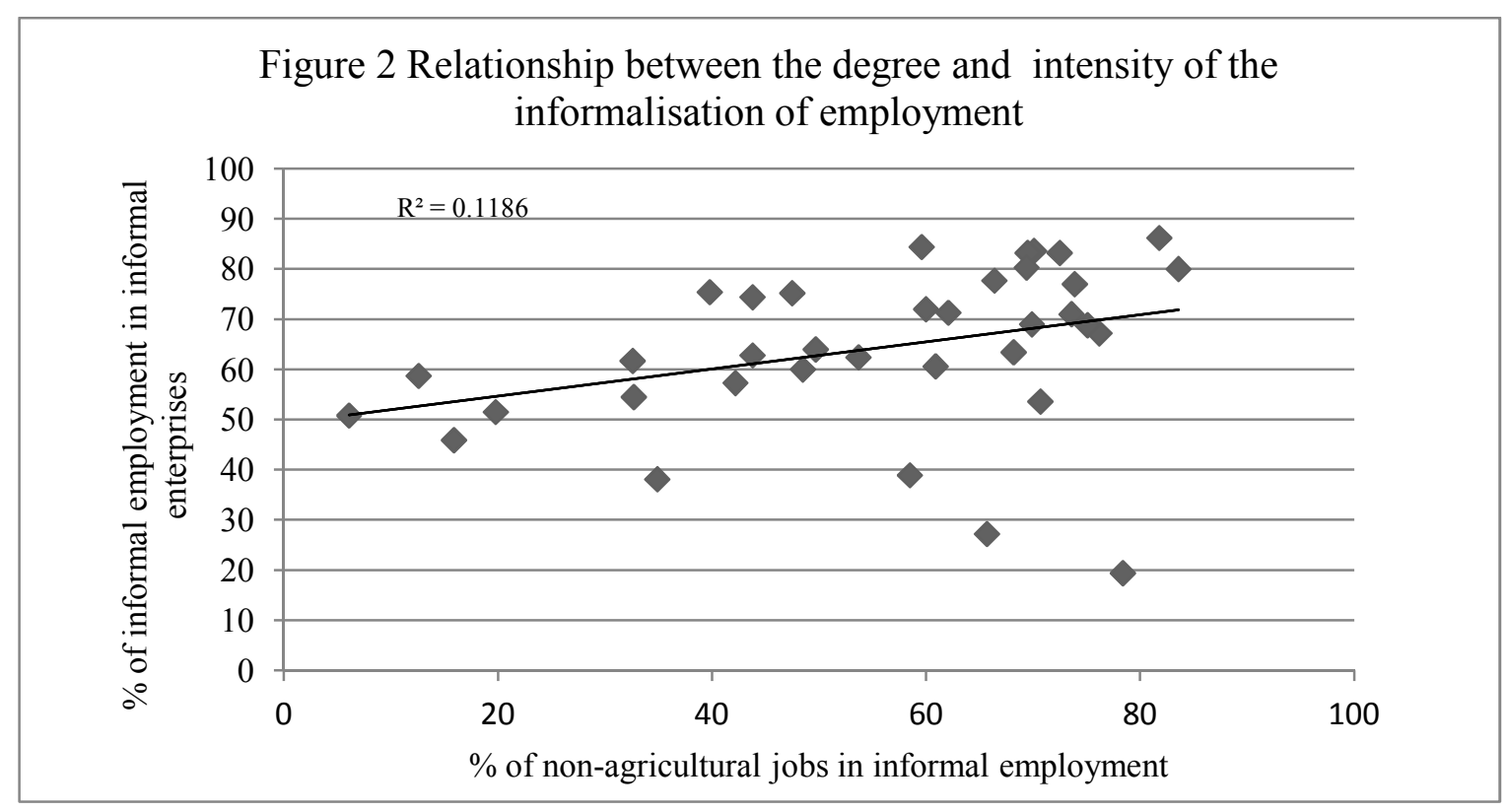

